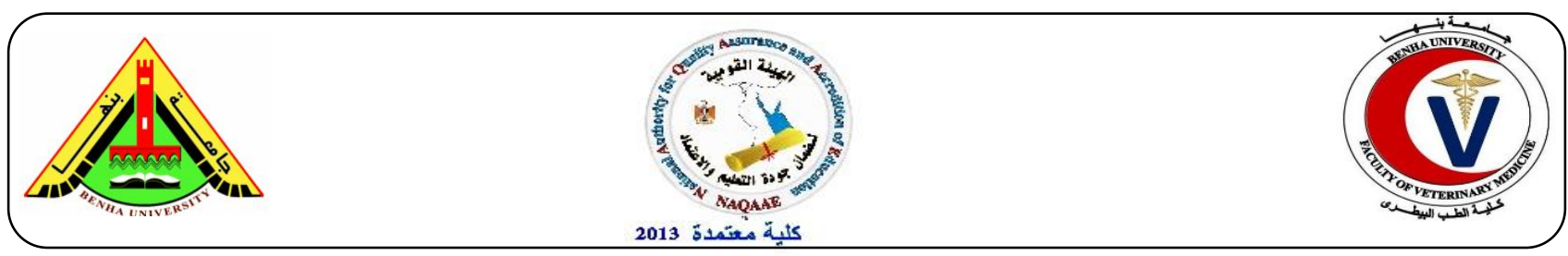

\title{
Bacteriological evaluation of fresh and cooked meat meals served at a university hostel restaurant
}

Hassan, M.A. ${ }^{1}$, Rasha Elsabagh ${ }^{1}$, Nesreen Eleiwa ${ }^{2}$, Hanady Zohdy ${ }^{2}$.

${ }^{1}$ Food Control Department. Faculty of Veterinary Medicine, Benha University

${ }^{2}$ Food Control Department, Animal Health Research Institute, Tanta Branch.

\section{A B S T R A C T}

A total of 90 random sample of fresh and cooked meat (boiled) (45 of each) were collected from university student hostel, and examined bacteriologically to detect its safety. Aerobic plate count (APC), Staphylococcal counts and Coliforms count were examined, Isolation and identification to E.coli. The obtained results in this study indicated that the mean value of APC was $6.32 \times 10^{5} \pm$ $1.17 \times 10^{5} \mathrm{cfu} / \mathrm{g}$ for fresh meat and $1.08 \times 10^{5} \pm 0.24 \times 10^{5} \mathrm{cfu} / \mathrm{g}$ for cooked meat; furthermore APC was detected in $75.5 \%$ in fresh meat according to EOS (2008) and $86.7 \%$ in cooked meat according to Center for Food Safety 2014. The obtained results indicated that the mean values of Staphylococcal count and coliforms in examined samples were $1.10 \times 10^{3} \pm 0.21 \times 10^{3}$ and $9.95 \times 10^{3} \pm 2.03 \times 10^{3}$ $\left(\mathrm{cfu} / \mathrm{g}\right.$ ) for fresh meat and $7.78 \times 10^{2} \pm 1.64 \times 10^{2}$ and $2.14 \times 10^{3} \pm 0.51 \times 10^{3}$ (cfu/g) for cooked meat. Incidence of E.coli from fresh meat was $28.9 \%$ and $24.4 \%$ from cooked meat. These results indicate that fresh meat had higher significant results than cooked meat due to cooked meat were subjected to heat treatment that lead to killing of microorganisms, moreover, presence of E.coli in cooked meat indicated post heat treatment infection.

Keywords: Meat meals, APC, Staphylococcal count, Coliforms count and E.coli.

(http://www.bvmi.bu.edu.eg)

(BVMJ-34(1): 269-276, 2018)

\section{INTRODUCTION}

Meat constitutes the important food item of the meal served at university student hostels because of its palatability and highly nutritional value by protein and vitamins. For this high nutritional value, it offers a highly favorable environment for the growth of pathogenic microorganisms. The risk of bacterial food borne diseases increases when meat meals are prepared in kitchens, as in student accommodation and youth hostels.

WHO defines 'Food Safety' as that food will not cause harm to the consumer when prepared or eaten in accordance with its intended use. While Food Hygiene is defined, as all the measures necessary to ensure the safety, soundness of food at all stages of its production or manufacture until its final consumption(WHO, 2010).

Fresh meat samples were the most contaminated ones with $S$. aureus than other samples. This may reflect bad hygienic practices during different stages from slaughtering, handling practices, transportation and excessive handling during preparation of the meal, and presence of this microorganism in post processing meat meal 
indicated post processing contamination (Shaltout et al., 2015).

Improper practices responsible for microbial food borne illness have been well typically involve cross contamination of raw and cooked food, inadequate cooking and storage at inappropriate temperatures. (Egan et al., 2007)

In the USA 77.7 billion dollars was lost annually to investigate foodborne illnesses associated with 31 foodborne pathogens and spoilage microorganisms which lead to a serious economic loss (Scharff, 2012).

Staphylococcal food poisoning is the result of performed enterotoxins that are produced by certain strains of $S$. aureus resulting in symptoms of intoxication, not an infection. The most common symptoms appear approximately 3-8 hrs after ingestion and include nausea, vomiting, abdominal cramps and diarrhea. Generally, symptoms are short in duration (approximately $24-48$ hrs) (Sandle and McKillip, 2004)

The presence of coliforms group in meat has an epidemiological interest as some of members are pathogenic, and may result in serious infections and food poisoning. Thus, the total coliforms count may be used as a board base indicating fecal contamination of meat due to inadequate processing and / or post processing recontamination of meat (ICMSF, 1998)

Members of the Gram negative bacteria e.g. E.coli is widely distributed in the environment. Contaminated food and water are the major sources by which the bacteria spread, E. coli is commonly used as surrogate indicator, and its presence in food generally indicates direct and indirect fecal contamination. (Clarence et al., 2009)

EPEC as the first group of E. coli causing diarrheal illness in humans. Symptoms in general appear about 12-36 hours after ingestion and include vomiting and diarrhea accompanied by low grade fever.
Stools are rarely bloody. In infants the disease can be severe lasting longer than 2 weeks (Bolton et al., 2006)

So the aim of this study is to examine the bacteriological status of fresh and cooked meat meals in university student hostel to evaluate its safety.

\section{Materials and methods}

\subsection{Collection of samples:}

A total of 90 random samples of fresh and cooked meat (boiled) (45 of each) were collected from a university hostel restaurant at various times. The collected samples examined bacteriologically to evaluate their safety for human consumption.

\subsection{Bacteriological examination:}

Preparation of samples was performed according to (ICMSF, 2006).

The prepared samples were subjected to the following examinations:

Aerobic Plate Count, Staphylococcal count and Coliforms count was performed on fresh and cooked meat according to ICMSF 2006. (ICMSF, 2006)

Isolation and identification of $E$. coli (ISO, 2007):

A Loopful from positive Eijkman's tube was separately streaked onto Eosin Methylene Blue (E.M.B.) agar plates, suspected colonies were metallic green in color with dark purple center. Separated colonies were purified and inoculated into nutrient agar slope tubes for further identification.

Acceptability of samples was compared to EOS (2008) for fresh meat and to Center for Food Safety (2014) for cooked meat.

\section{RESULTS}

It is evident from the results recorded in Table (1) that the APC/g of the examined fresh and cooked meat samples ranged from $8.5 \times 10^{3}$ to $1.2 \times 10^{6}$ with an average of $6.32 \times 10^{5} \pm$ $1.17 \times 10^{5}$ for fresh meat and $3.1 \times 10^{3}$ to 
$4.9 \times 10^{5}$ with an average of $1.08 \times 10^{5} \pm$ $0.24 \times 10^{5}$.

According to EOS (2008), Accepted samples of fresh meat based on their APC $/ \mathrm{g}$ was $75.5 \%$ and $86.7 \%$ for cooked meat according to Center for Food Safety 2014. Table (2)

Results achieved in Table (3) showed the statistical analytical results of staphylococcal count $(\mathrm{cfu} / \mathrm{g})$ in the examined fresh and cooked meat samples. For fresh meat ranged from $2 \times 10^{2}$ to $5 \times 10^{3}$ with average of $1.10 \times 10^{3} \pm 0.21 \times 10^{3}$. And for cooked meat ranged from $1 \times 10^{2}$ to $2 \times 10^{3}$ with average of $7.78 \times 10^{2} \pm 1.64 \times 10^{2}$.

Accepted samples of fresh meat based on their Staphylococcal count /g was $68.9 \%$ according to EOS (2008) and $77.8 \%$ for cooked meat according to Center for Food Safety 2014. Table (4)

Table (5) revealed that mean values of Coliforms counts in examined samples were
$9.95 \times 10^{3} \pm 2.03 \times 10^{3}$ for fresh meat and $2.14 \times 10^{3} \pm 0.51 \times 10^{3}$ for cooked meat.

According to EOS (2008), Accepted samples of fresh meat was $60 \%$ based on their Coliforms count $/ \mathrm{g}$ and $73.3 \%$ for cooked meat according to Center for Food Safety 2014.Table(6)

Table (6) indicated that serotyping of E. coli isolated from the examined samples of fresh and cooked meat. EHEC (O26 : H11, O91 : $\mathrm{H} 21$ and O111: H2) with an incidence (6.7, 4.5 and $4.5 \%)$ for fresh meat and (6.7, 0 and 4.5\%) for cooked meat. Also, EPEC (O55: H7, O113: H4, O121: $\mathrm{H} 7$ and O146: H21) with an incidence $(4.5,0,4.5$ and $0 \%$ ) for fresh meat and (2.2, 2.2, 0 and 2.2\%) for cooked meat, and for EIEC O124 was isolated from fresh meat only with an incidence $2.2 \%$. While ETEC O127: H2 was isolated from both fresh and cooked meat with an incidence $2.2 \%$ and $6.7 \%$, respectively.

Table (1): Aerobic Plate Count (cfu/g) in the examined fresh and cooked meat. samples $(\mathrm{n}=45)$.

$\begin{array}{llll}\text { Meat status } & \text { Min. } & \text { Max. } & \text { Mean } \pm \text { S.E } \\ \text { Fresh meat } & 8.5 \times 10^{3} & 1.2 \times 10^{6} & 6.32 \times 10^{5} \pm 1.17 \times 10^{5} \mathrm{a} \\ \text { Cooked meat } & 3.1 \times 10^{3} & 4.9 \times 10^{5} & 1.08 \times 10^{5} \pm 0.24 \times 10^{5 b}\end{array}$

Table (2): Acceptability of the examined fresh and cooked meat samples based on their APC/g. $(n=45)$.

\begin{tabular}{lccccc}
\hline & & \multicolumn{2}{c}{ Accepted samples } & \multicolumn{2}{c}{ Unaccepted samples } \\
Meat status & APC $/ \mathrm{g}^{*}$ & No. & $\%$ & No. & $\%$ \\
Fresh meat & $>10^{6}$ & 34 & 75.5 & 11 & 24.5 \\
Cooked meat & $>10^{5}$ & 41 & 91.1 & 4 & 8.9 \\
\hline
\end{tabular}

* Egyptian Organization for Standardization "EOS" (2008) no. 4334/2008 for fresh meat.

** Center for Food Safety (2014) 
Table (3): Staphylococcal count (cfu/g) in the examined fresh and cooked meat samples $(\mathrm{n}=45)$.

\begin{tabular}{llll} 
Meat status & Min & Max & Mean \pm S.E \\
Fresh meat & $2 \times 10^{2}$ & $5 \times 10^{3}$ & $1.10 \times 10^{3} \pm 0.21 \times 10^{3 \mathrm{a}}$ \\
Cooked meat & $1 \times 10^{2}$ & $2 \times 10^{3}$ & $7.78 \times 10^{2} \pm 1.64 \times 10^{2 \mathrm{a}}$ \\
\hline
\end{tabular}

Table (4): Acceptability of the examined fresh and cooked meat samples based on their Staphylococcal count /g $(\mathrm{n}=45)$.

\begin{tabular}{llllll}
\hline & & \multicolumn{2}{c}{ Accepted samples } & \multicolumn{2}{c}{ Unaccepted samples } \\
Meat status & Staphylococci $/ \mathrm{g}^{*}$ & No. & $\%$ & No. & $\%$ \\
Fresh meat & $>10^{2}$ & 32 & 68.9 & 13 & 31.1 \\
Cooked meat & $>10^{2}$ & 35 & 77.8 & 10 & 22.2 \\
\hline
\end{tabular}

Table (5): Coliforms count (cfu/g) in the examined fresh and cooked meat samples $(n=45)$.

$\begin{array}{llll}\text { Meat status } & \text { Min. } & \text { Max. } & \text { Mean } \pm \text { S.E }^{*} \\ \text { Fresh meat } & 5 \times 10^{2} & 2.6 \times 10^{4} & 9.95 \times 10^{3} \pm 2.03 \times 10^{3} \text { a } \\ \text { Cooked meat } & 1 \times 10^{2} & 7.4 \times 10^{3} & 2.14 \times 10^{3} \pm 0.51 \times 10^{3 \mathrm{~b}}\end{array}$

Table (6): Acceptability of the examined fresh and cooked meat samples based on their Coliformis count $/ g(n=45)$.

\begin{tabular}{lccccc}
\hline & & \multicolumn{2}{c}{ Accepted samples } & \multicolumn{2}{c}{ Unaccepted samples } \\
Meat status & Coliform $/ \mathrm{g}^{*}$ & No. & $\%$ & No. & $\%$ \\
Fresh meat & $>10^{2}$ & 27 & 60 & 18 & 40 \\
Cooked meat & $>10^{2}$ & 33 & 73.3 & 12 & 26.7 \\
\hline
\end{tabular}

* Egyptian Organization for Standardization "EOS" (2008) no. 4334/2008 for fresh meat. ** Center for Food Safety (2014)

\section{DISCUSSION}

The nutritional value of meat is derived from its high protein content. The fats found in meat can also be a valuable source of energy for the body. Meat contains important minerals, including iron, phosphorus, zinc and the complete range of $\mathrm{B}$ vitamins, some of which like vitamin B12 can usually only be found in foods derived from animals.

Every processing done to meat from the point of slaughtering until it is ready for consumption can add to the bacterial load of 
this meat. Thus, meat products are considered as a major vehicle of most reported foodborne outbreaks and may be contaminated with several types of organisms through long chain of preparation, handling of raw meat, processing, distribution, storage and retailing (Shawish, 2015).

The obtained results were nearly similar to those reported by Kirralla (2007) who found that the mean values of APC was $9.40 \mathrm{x}$ $10^{5} \mathrm{cfu} / \mathrm{g}$ for cooked meat samples, ShafikNagwa (2013) who found that mean value of APC was $2 \times 10^{5} \pm 1 \times 10^{5} \mathrm{cfu} / \mathrm{g}$ for kofta

However higher findings were obtained by Mukhopadhyay et al. (2009) found that the mean value of APC in fresh beef were 4.6 $\mathrm{x} 10^{6} \mathrm{cfu} / \mathrm{g}$. Ghanem (2009) who found that the mean value of APC was $6.38 \times 10^{7} \pm 2.27$ x $10^{7} \mathrm{cfu} / \mathrm{g}$ in examined samples of ready-toeat meat products.

While lower results were recorded by ElTaher- Amna (2009) who found that the mean values of APC of cooked meat was $4.21 \times 10^{3}$ cfu/g, Okonko et al. (2010) found that the aerobic plate count on the fresh meat was between $2.62 \times 10^{4}$ to $4.84 \times 10^{4} \mathrm{cfu} / \mathrm{g}$.

The variation in bacterial count between fresh and cooked meat products could be attributed to heat treatment during cooking but cooked meat has count high also due to post heat treatment infection and polluted hand of workers (fecal contamination).

Nearly similar results were obtained by Lotfi et al. (1990) who found that the mean value of Staphylococcal counts in examined samples of cooked meat were $9.3 \times 10^{2}$ and $2.5 \times 10^{2}$ cfu/g.

However, higher findings were obtained by Kirralla (2007) who reported that the mean value of Staphylococcal counts was $2.45 \times 10^{5} \mathrm{cfu} / \mathrm{g}$ in examined cooked meat samples. Arab (2010) indicated that the mean value of Staphylococcal count was $2.4 \times 10^{5}$ $\mathrm{cfu} / \mathrm{g}$ for fresh meat.
Staphylococcal food poisoning (SFP) is one of the most prevalent causes of gastroenteritis worldwide. Symptoms of SFP have a rapid onset ( 2 to 6 hours) of abdominal cramps, nausea and vomiting, sometimes followed by diarrhea. Patients become symptomatic within 2-4 hours after ingestion of thermo stable staphylococcal enterotoxins of an approximate dose of 0.1 to $1.0 \mathrm{mg} / \mathrm{kg}$ of body weight. (Stewart et al., 2005)

Nearly similar results obtained by Yassien and El-Essawy (1990) who found that mean value of coliform in ready to eat meals was 9 $\times 10^{3} \mathrm{cfu} / \mathrm{g}$.

While higher results obtained by Eldaly et al. (1988) who found that the mean value of coliforms count of examined minced meat samples was $45 \times 10^{5} \mathrm{cfu} / \mathrm{g}$.

However lower findings were recorded by Lotfi et al. (1990) who mentioned that mean value of coliforms of cooked meat collected from Assiut University Hospital was $9.3 \times 10^{2}$ cfu/g, Kirralla (2007) who reported that the mean values of coliform count for cooked meat samples was $4 \times 10^{2} \mathrm{cfu} / \mathrm{g}$.

Coliform bacteria have probably received more attention than the most other groups of bacteria occurring in meat for their significance as indicator organisms of fecal contamination and their ability to grow well over wide range of temperature below $10^{\circ} \mathrm{C}$ up to $46{ }^{\circ} \mathrm{C}$ (Gill et al., 1998).

Many authors isolated E.coli with different strains from different meat samples: ElTaher- Amna (2009) who isolated E.coli from $13.33 \%$ of the examined cooked meat. Abdel Fattah - Walaa (2014) who found that that incidence of E.coli in the examined samples of RTE sandwiches were $40 \%$ for beef kofta, $33.3 \%$ for beef shawerma. Food, I. (2015) mentioned the results also showed that $89.5 \%$ of meat samples contaminated with $E$. coli. E.coli is one of the major threats to public health due to consumption of insufficient cooked meat and meat products. The 
microorganism is known as a foodborne pathogens evening the presence of low levels. (Aruno et al., 2007)

After ingestion of EHEC and a subsequent incubation period of 2 to 3 days, patients (most frequently children) develop watery diarrhea that is typically accompanied by abdominal pain. Bloody diarrhea appeared after a 2-4-day interval in about $80 \%$ of cases. Approximately, one week with range of 3 to 13 days after the onset of diarrhea, $10 \%$ to $15 \%$ of patients (data for children under 10 years of age) develop HUS (haemolytic uremic syndrome) (Brzuszkiewicz et al., 2011).

Fresh meat higher in incidence than cooked meat due to cooked meat subjected to heat treatment lead to killing of microbe but result in cooked high also because post heat treatment infection and fecal contamination.

Finally, cooked meat meals had a lower bacterial contamination than fresh ones because the heat treatment that those meals subjected to it safe for student's health. The present study proved that meat meals are considered of public health hazard, due to bad hygienic preparation of the meals at kitchen of student and the temperature for boiling was insufficient to kill bacteria as well as post cooking contamination with handling.

\section{CONCLUSION}

The present study revealed that fresh meat had higher significant results than cooked meat in APC, coliform count and staphylococcal count due to heat treatment in cooking process. Presence of E.coli indicated fecal contamination so good hygienic measure and application of HACCP system must be applied.

\section{REFERENCES}

Abdel Fattah - Walaa, M.G.A. 2014. Incidence of salmonellae and Escherichia coli in RTE foods M.V.Sc
(Meat Hygiene), Fac. Vet. Med. Benha Univ. Egypt.

Arab, W.S.S. 2010. Quality improvement of meat meals provided by a University Student Restaurant, Ph. D. Thesis, Meat Hygiene, Fac. Vet. Med., Benha. Univ. Egypt.

Aruno, O.O; Aydn, A.; Vural, A.I.; Cffcoglu, G. and Aksu, H. 2007. Determination of E.coli $O 157$ in raw and cooked Doner Kabab by using IMS technique. Medcyna-Weterynaryina, 63(10):1181- 1183.

Bolton, D. J.; Duffy, G.; Baylis, C. L.; Tozzoli, R.; Morabito, S.; Wasteson, Y. and Lofdahl, S. 2006. Pathogenicity, Virulence and Emerging, Pathogenic Escherichia coli. Co-ordination action, Food -CT$2006-036256$.

Brzuszkiewicz, E.; Thurmer, A.; Schuldes, J.; Leimbach, A. and Liesegang, $H$. 2011. Genome sequence analyses of two isolates from the recent Escherichia coli outbreak in Germany reveal the emergence of a new pathotype: Entero- AggregativeHaemorrhagic Escherichia coli (EAHEC). Arch. Microbiol., 193(12):883-891.

Center for Food Safety 2014. Microbiological guidelines for foods "ready- to- eat foods in general and specific food items". The expert committee on food safety, 43/F, Queensway government offices, 66 Queensway, Hong Kong.

Clarence, S.Y.; Nwinyi, O. and Chinedu, S.N. 2009. Assessment of bacteriological quality of ready to eat food (Meat pie) in Benin City metropolis, Nigeria. African J. Microbiol., Res., 3(6).pp.390-395. ISSN 1996-0808.

Egan, M.B.; Raats, M.M.; Grubb, S.M.; Eves, A.; Lumbers, M.L.; Dean, M.S. and 
Adams, M.R. 2007. A review of food safety and food hygiene training studies in the commercial sector food control,18:1180-1190.

Eldaly, E.; Saleh, E. and Abdel Galil, Y. 1988. Prevalence of B.cereus in some meat products. Bull. Fac. Sci. Zagazig Univ. Egypt. 10(part one)

El-Taher-Amna, M. 2009. Impact of temperature abuse on safety of food offered in a University Student Restaurant. M.V. Sc. Thesis, Meat Hygiene, Fac. Vet. Med. Moshtohor. Benha Univ. Egypt.

"EOS" Egyptian Organization for Standardization 2008. Reports related to No 4334/2008 for fresh beef. Egyptian Standards, Ministry of Industry, Egypt.

Food, I. 2015. Prevalence of foodborne pathogens in meat samples in Palestine, 22(5), 1806-1812.

Ghanem, S.H.A 2009. Microbiological status of some ready to eat meat products. M.V.Sc., Thesis (Meat Hygiene), Fac.Vet.Med ., Benha Univ. Egypt.

Gill, C; McGinnis, J. and Bryan, J. 1998.

Microbiological contamination of meat during the skinning of beef hind quarters at three slaughtering plants. J. Food Products, 43(3): 175-184.

International Commission and Microbiological Specification for Foods "ICMSF" 1998.

Microorganisms in Foods. Microbial Ecology of Foods Commodities. Blackie Academic and Professional, London, New York, Tokyo, Melbourne, Madress.

International commission of Microbiological Specification for Foods "ICMSF" 2006. Microorganisms in Food. I.Their Significance and methods of enumeration. $3^{\text {rd }}$ Ed. Univ. of Toronto, Canada.
International Specifications Organization "ISO" 2007. Microbiology of Food and Animal Feeding Stuffs Guidelines on Preparation and Production of Culture Media - Part 2. Practical Guidelines on Performance Testing of Culture Media. ISO, Geneva.

Kirralia, G.A. 2007. Sanitary status of meat meals of students of tanta university. M.V.Sc. Thesis meat hygiene, fac. Vet. Med., Kafr El- Shiekh Univ. Egypt.

Lotfi, A.; Youssef, H.; Hefnawy, Y.; ElTimawy, A. and Nassr, A. 1990. Sanitary statuses of meat meals in Assuit University hospitals. Assuit Vet. Med. J. 23(46):126. Egypt.

Mukhopadhyay, H.K.; Pillai, R.M.; Pal, U.K. and Kumar,V.JA.J. 2009. Microbial quality of fresh chevon and beef in retail outlets of Pondicherry. Tamilnadu J. Vet. Ani. Sci., 5(1):3336.

Okonko, I.O.; Ukut I-OE.; Ikpoh, I.S.; Nkang, A.O.; Udeze, A.O.; Babalola, T.A.; Mejeha, O.K. and Fajobi, E.A. 2010. Assessment of bacteriological quality of fresh meats sold in Calabar metropolis, Nigeria. Electro. J. Environ. Agri. Chemist., 9 (1): 89100.

Sandle, M.K. and Mckillip, J.L. 2004. Virulence and recovery of $S$. aureus relevant to the food industry using improvements on traditional approaches. J. Food Control. 15:5-10.

Scharff, R.L. 2012. Economic burden from health losses due to foodborne illness in the United States. J. Food Prot., 75(1): 123-131.

Shafik-Nagwa, M. 2013. Staphylococcal food poisoning associated with fast foods. M.V.Sc. (Meat Hygiene), Fac.Vet.Med., Benha Univ. Egypt. 
Shaltout, F. A., Zakaria. I. M., Jehan Eltanani1, Asmaa S. Elmelegy, 2015. Microbiological status of meat and chicken received to Univ. student hostel.

Shawish, R. R. M. 2015. "Prevalence of shiga toxin-producing E.coli in some beef products". Ph.D. Thesis (Meat Hygiene). Fac. Vet. Med., Menoufia Univ. (Sadatbranch), Egypt.

Stewart, C. M.; Cole, M. B. and Schaffner, D.W. 2005. "Managing the risk of staphylococcal food poisoning from Cream- Filled Backed Goods to Meet a Food Safety Objectives". J. Food Prot., 7(66):1310-1315.

World Health Organization "WHO" 2010. Microbial safety of foods in industrial area, Nairobi, Res. J. Microbial., 7:297-308.

Yassien, N.A. and EL-Essawy, H.H. 1990. Bacterial quality of ready to eat meals in air catering. Vet. Med. J. Giza. No.1, 